\title{
Investigating the Attitude and Perception of Consumers Towards Purchasing Food Products from Supermarket Through Online Trading
}

\author{
Eda ILBASMIS \\ Burhan OZKAN \\ Wasiu O. FAWOLE \\ Yesim KARAKAYA
}

Department of Agricultural Economics, Akdeniz University, Faculty of Agriculture, Dumlupinar Boulevard, Antalya, Turkey

\begin{abstract}
The aim of this study is to examine the attitudes and perception of consumers in Antalya province towards purchase of food productions from supermarket through online trading system and factors that influence such perception. To achieve the objective of this study, face to face interview were conducted with consumers in Antalya province and data collected were subsequently analysed using logistic regression. The scope of the research study covers that socio-demographic charateristics of consumers, internet access and usage status and supermarkets' views on online trading services are some of the factors that drove the attitudes and perception of consumers towards food products purchase.
\end{abstract}

Keywords: Consumers, food products, online trading, logistic regression analysis 